B. Kholod, Dr. Sc. (Econ.), Prof., orcid.org/0000-0002-2901-7936, A. Zadoia, Dr. Sc. (Econ.), Prof., orcid.org/0000-0003-4620-6920, O.Zadoia, Cand. Sc. (Econ.), orcid.org/0000-0002-4251-3061

\title{
POLYCENTRISM OF THE MODERN WORLD: A METHODOLOGY FOR DISCOVERING WORLD LEADERS
}

Purpose. Development of a methodology for identifying leaders of modern world development based on the ranking of applicants by key indicators that reflect the status and trends of their development.

Methodology. The development of a methodology for identifying world leaders is based on four criteria: the country's economic potential; opportunities to influence other countries and the development of the world economy as a whole; efficiency of available potential use; the country's innovation. The calculation of the Global Leadership Index is based on comparing the corresponding indicator for each country with the best indicator in the world and adjusting it by the weight factor. The sum of the results will be shown by the Global Leadership Index.

Finding. Based on the analysis, it is revealed that the undisputed economic leaders of the modern world are the US and the EU, which have virtually the same value of the Global Leadership Index. However, due to the monolithic character the United States position is more preferable. The role of leaders can also be claimed by China and Germany. Although China is still inferior to the US and the EU, the dynamics of its economic development and the magnitude of its impact on the world give reason to predict its approach to leaders. On the contrary, Russia and India can still only claim to be regional leaders, not world leaders.

Originality. The original methodology for calculating the Global Leadership Index, based on the country's ranking of GDP, exports of goods and FDI in global indicators, as well as GDP per capita and Global Index, has been proposed.

Practical value. The results of the study can be used to identify trends in world leaders' changes and to predict possible directions for exacerbation of contradictions on this basis.

Keywords: models of the world economy, polycentrism, world economic leaders, Global Leadership Index

Introduction. The world economy has never been homogeneous. It has always included national economies that differed in the level of development, economic models, degree of socialization, dominant religious denominations, and so on. However, at different stages of development, these or other countries have become world leaders. They achieved this status in various ways, but for centuries the main one has been military might. Times change, and with them the criteria that shape a leader's status change too. This process was particularly dynamic in the twentieth and early twenty first centuries. If once the dominant positions of leaders could last for centuries, then recently changes in the group of leaders occur almost every 15-20 years. One hundred years ago, the UK was one of the undisputed world leaders, and today many researchers do not even include it in the TOP-5.

The dynamism of modern development, the change in the paradigm of world leadership causes considerable interest in these problems from the economic and political science. After all, having an adequate picture of the modern world has not only a cognitive effect. It provides an opportunity to predict potential leadership changes and the expected exacerbation of contradictions between them. This is important not only for the countries that claim to be leading, but also for everyone else, as it allows them to formulate their foreign economic strategies and priorities more clearly.

Literature review. In economic science there are a lot of attempts to build a general model of the world economy. There are several options for the world view, depending on the stage of development of the world economy and world politics. For a long period of time, the world was viewed as bipolar or bicentric: the US at one pole and the Soviet Union at the other. And fundamental differences in views on the prospects for the development of the world and ways of solving current problems of the world economy (but not simply economic indicators) were at the heart of such a division. Each pole (center) united around itself a whole group of countries to which it relied, trying to influence the world economy and politics.

(c) Kholod B., Zadoia A., Zadoia O., 2020
Gradually, as a result of the growth of economies in other countries of the world and increasing their influence on world processes, researchers started talking about many centers of the world economy. One of the first to argue for was Sol Cohen, who talked about four world economic centers: the US, Western Europe, the Soviet Union and China. However, even under these conditions, the bipolarity of the world remains: West - East. Other participants in the world economy were determined in their choice for economic and political orientation. Therefore, the world was divided into three groups of countries: pro-American (with the US in the center), pro-Soviet (with the USSR in the center) and non-aligned countries. They were the object of a rather fierce fight between the two poles to expand their sphere of influence.

In the following years, aspects of the study have changed somewhat. Reducing international tension has allowed more attention to be paid to economic indicators when defining world centers. Japan was added to the previously named four. In addition, Cohen's approach is interesting, which is to speak of world-centers (first-order leaders), regional centers (second-order leaders), etc. This classification allows us to structure and shape the world economy as a system.

The model of the world economy, built on the principle of "center - periphery", was quite popular in its time. Its ideologist was the American scientist I. Wallerstein. According to this model, the world can be imagined as a definite center (nucleus), spanning the semi-periphery and periphery. However, in the construction of such a model, in our opinion, much attention was paid to non-economic factors (for example, developed capitalist countries were considered the center (nucleus), and the socialist countries of the time were the semi-periphery). To some extent, this approach was justified, since there was indeed a confrontation between the capitalist and socialist systems, which largely defined the entire structure of the "world system" (in I. Wallerstein's terminology).

Today, however, the situation in the world has changed. In terms of building the economic model of society, the former socialist and capitalist countries are little different. Of course, there have been some aspirations to play a leading role in the 
modern world, which are not always based on economic leadership, but the weight of economic factors has increased significantly. Moreover, the most developed countries are not the unified center. There are significant contradictions between them, and their attitude to countries with lower levels of development is also not the same. These countries are competing to expand their spheres of influence in the world. That is why, in our opinion, the polycentric model is more in line with the current stage of development of the world economy.

However, it has a number of differences from those models that were built in the 70s of the last century. Firstly, the composition of world and regional centers has become quite dynamic. Significant differences in the economic dynamics of individual countries give rise to a fairly rapid change in the ratio of their strength. Therefore, the number of world centers and their composition may change in the short term. Secondly, there is no clear delineation of the center influence (unlike the existing once clear division into "capitalist" and "socialist" camps). Many countries have close links to various world centers in various areas. Thirdly, the centers of the world economy are quite dependent on each other because they work closely as partners in world trade, capital movements and the scientific and technical field. However, this does not prevent them from competing with each other.

Of course, the selection of world economic centers is only the first step in the structuring of the mega-economy. It would be fair to talk about first- or second-tier local economic centers, their areas of influence, and more. However, this is a major independent problem that we do not address in our study.

The next step in exploring the polycentric structure of the modern world should be to determine the methodology and methods for identifying these centers. There are numerous studies that substantiate certain indicators that allow us to speak about some countries as world economic centers. In particular, O.A. Chugayev's research is quite interesting. He uses the notion of economic power of the state as a criterion for the allocation of world and regional centers [1]. He has developed a methodology for assessing the hard and soft economic power of the country, which makes it possible to rank all countries in the world, depending on the integrated indicator. However, the proposed calculations are rather cumbersome and time consuming, and therefore their scope becomes somewhat limited. In addition, the information base for calculations is not systematically updated, which also narrows the possibilities of using the proposed methodology.

Purpose. The purpose of our study is to develop a methodology for identifying leaders of modern world development based on the ranking of applicants by key indicators that reflect the status and trends of development, using public information.

Methods. In our view, a leading country, which claims to be one of the world's economic centers, must meet several criteria.

Firstly, it must have sufficient economic potential to enable it to both solve large-scale internal problems and be able to withstand severe external shocks. Today, gross domestic product (GDP) can be considered as the most adequate indicator that meets these requirements. There are several options for calculating GDP for international comparisons. The most common of these is the current dollar rate and purchasing power parity. We have already analyzed the differences between these indicators. Each of them has its advantages and disadvantages, which determines the most acceptable scope of their use. For the purposes of measuring economic potential, in our opinion, it is more appropriate to calculate the purchasing power parity. In this case, we eliminate the influence of deliberate manipulation of the market rate by the governments of individual countries, which deliberately undervalue the national currency to create additional benefits for their exporters. Purchasing power parity is also less dependent on the currency market and characterizes the state of the national economy more objectively. It is on the basis of this indicator that preliminary selection of applicants can be made. In such selection, we introduce a restriction that the gap between the indicator of the country holding the first position and the country of the last applicant should not exceed 6 times. Otherwise, there is no need to speak of such a country as a potential world economic center.

Secondly, the leader must play a significant role in international economic relations and be able to influence other countries in some way. This can be judged on the basis of two indicators: the volume of exports (namely exports, since imports are more characterized not by the external influence but by its dependence, although for the sake of fairness it must be acknowledged that exports can cause external dependence) and the volume of foreign direct investment. At the same time, not only the volume of exports (or imports) is important, but also its geographical structure, because the high proportion of a country, even in the export of a leader, puts it in some dependence on it and narrows the corridor of freedom in the world market. In our view, the potential threat of such dependence arises when the specific weight of one partner country exceeds $20 \%$. Therefore, a leader must have a fairly diversified foreign trade structure.

Thirdly, it is important for a leader not only to have significant economic resources, but also to use them effectively, ensuring a decent standard of living for citizens. After all, one or another center is united not only because it is large, but also because its form of existence deserves imitation [2]. Of course, it would be possible to use the latest various international indices, such as the Human Development Index, the Human Capital Index, the Inclusive Development Index, and the like. However, first of all, these figures are calculated recently and not regularly. And secondly, they do not include many countries, which limits their practical application. Therefore, we will use the most affordable indicator, namely GDP per capita. If necessary, it can be analyzed in dynamics, estimating the change of ratios at different stages of development.

Fourthly, the centers of the global economy must be leaders in the innovation field as well. Without tuning for innovation, it is hardly possible to stay on top for a long time, even if for one or another reasons the country found itself there. Innovation is a rather complex characteristic that a single indicator cannot reflect. Therefore, we use our estimates from the Global Innovation Index, which is calculated annually (since 2007) by INSEAD International Business School, Cornell University, US and World Intellectual Property Organization, WIPO.

Results. We use these methodological bases to identify the modern centers of the world economy. Table 1 contains information on six countries which ranked first in the GDP of a country calculated on purchasing power parity. Extending this list makes no sense, since the gap between the leader (China) and the $7^{\text {th }}$ (Indonesia) country is more than 6 times, and therefore the latter cannot claim to be a world center. The list also includes the integration grouping of countries (the European Union, EU). With certain conventions, this grouping can be referred to as a world economic center, since in international economic relations the EU most often acts as a common position of its members, and therefore can be considered as a unit of the world economy. However, some convention of this assumption should be understood, since, firstly, the resources of the EU Member States are not fully integrated and each country can independently determine the directions of their use; secondly, the composition of the EU is far from heterogeneous: it includes countries with a high level of economic development and considerable authority in the world arena, and "middle-class" countries that do not have attractive powers in relation to other countries of the world [3]; thirdly, disintegration processes have intensified within the EU today, weakening its power and authority in the world. However, a leader group may include Germany (an EU member) whose figure fits into the restrictions previously imposed. 
Key indicators of world leadership in 2017 [7, 8]

\begin{tabular}{|l|c|c|c|c|c|}
\hline Country & $\begin{array}{c}\text { GDP } \\
\text { (trillion } \\
\text { US\$) }\end{array}$ & $\begin{array}{c}\text { Export } \\
\text { (trillion } \\
\text { US\$) }\end{array}$ & $\begin{array}{c}\text { FDI } \\
\text { (trillion } \\
\text { US\$) }\end{array}$ & $\begin{array}{c}\text { GDP per } \\
\text { capita } \\
\text { (th.US\$) }\end{array}$ & $\begin{array}{c}\text { Global } \\
\text { Innovation } \\
\text { Index }\end{array}$ \\
\hline World & 127.8 & 17.310 & 34.730 & 17.5 & - \\
\hline China & $\mathbf{2 3 . 2}$ & $\mathbf{2 . 2 1 6}$ & 1.383 & 16.7 & 52.54 \\
\hline EU & 20.9 & 1.929 & $\mathbf{8 . 4 1 1}$ & 40.9 & 50.51 \\
\hline USA & 19.5 & 1.553 & 5.711 & 59.8 & 61.40 \\
\hline India & 9.5 & 0.304 & 0.155 & 7.2 & 35.47 \\
\hline Japan & 5.4 & 0.688 & 1.547 & 42.9 & 54.72 \\
\hline Germany & 4.2 & 1.434 & 2.298 & 50.8 & 58.38 \\
\hline Russia & 4.0 & 0.353 & 0.461 & 27.9 & 38.76 \\
\hline
\end{tabular}

The study of GDP shows at least two conclusions:

- there is no single country in the world economy, which is dominant today, as has been observed in previous years. The leader of this rating (China) produces $18 \%$ of the world GDP, which is not much different from the EU and the US indicators ( 16 and $15 \%$, respectively);

- clearly identifies a group of three entities (China, EU and US) that is significantly ahead of others: India's GDP, which ranks $4^{\text {th }}$ in the ranking, is twice less than US GDP in third position. There is reason to believe that these entities will emerge as world economic centers.

The analysis of the next indicator for the selected countries (the volume of exports of goods and services) shows its even smaller concentration in individual countries. China is the leader in this indicator. But it accounts for only $13 \%$ of world exports. Only the EU "crossed" the border at $10 \%(11 \%)$, and the US and Germany came closer to it (9 and $8 \%$ ). The variations of the same indicator in the group of selected countries are higher than in the previous one: China's exports are 7.3 times higher than India's.

It should be noted that by this indicator the group of leaders remains unchanged (China, EU, USA). And this to a certain extent confirms the opinion that the volume of exports is quite closely correlated with the GDP of the country.

But at the end of the group there were significant changes. Germany came in fourth place, while India moved up to last place.

As noted, we included exports in our analysis, because through them it is possible to influence the other world, making it dependent on the position of a leader. However, the excess weight of one partner as an external buyer or seller may pose a threat to the country. Therefore, we analyze the geographical structure of foreign trade activity of the selected countries (Table 2). Its analysis shows that:

- the leaders of the world economy are active in trade with each other. China has a special position here. In all selected countries, China is among the top 4 partners in both export and import. Moreover, in five cases out of six, China is the largest supplier of products from abroad. Similar rates are also high for the United States. However, if China is a major supplier, then the United States can be regarded as the main buyer of the product: this country ranks first among the markets for five of the six selected countries (excluding Russia).

Significantly more moderate indicators of importance as foreign trade partners are for other selected countries. Japan is an influential partner for China and the US. Germany is a significant buyer of Russian products and supplies to its markets, as well as a supplier of goods to Chinese markets. Russia may place itself in the fourth position among the largest suppliers to Germany. But India is not at all one of the largest partners for any of the selected countries;
The main foreign trade partners of the selected countries (2017) [7]

\begin{tabular}{|c|c|c|c|}
\hline Country & $\begin{array}{c}\text { Part in } \\
\text { export (\%) }\end{array}$ & Country & $\begin{array}{c}\text { Part in } \\
\text { import (\%) }\end{array}$ \\
\hline \multicolumn{4}{|c|}{ China } \\
\hline USA & 19.0 & South Korea & 9.7 \\
\hline Hon Kong & 12.4 & Japan & 9.1 \\
\hline Japan & 6.0 & USA & 8.5 \\
\hline South Korea & 4.5 & Germany & 5.3 \\
\hline \multicolumn{4}{|c|}{ USA } \\
\hline Canada & 18.3 & China & 21.6 \\
\hline Mexico & 15.7 & Mexico & 13.4 \\
\hline China & 8.4 & Canada & 12.8 \\
\hline Japan & 4.4 & Japan & 5.8 \\
\hline \multicolumn{4}{|c|}{$\mathbf{E U}$} \\
\hline USA & 20.7 & China & 20.1 \\
\hline China & 9.6 & USA & 14.5 \\
\hline Switzerland & 8.1 & Switzerland & 7.1 \\
\hline Turkey & 4.4 & Russia & 6.3 \\
\hline \multicolumn{4}{|c|}{ Germany } \\
\hline USA & 8.8 & The Netherlands & 13.8 \\
\hline France & 8.2 & China & 7.0 \\
\hline China & 6.8 & France & 6.6 \\
\hline The Netherlands & 6.7 & Belgium & 5.9 \\
\hline \multicolumn{4}{|c|}{ Russia } \\
\hline China & 10.9 & China & 21.2 \\
\hline The Netherlands & 10.0 & Germany & 10.7 \\
\hline Germany & 7.1 & USA & 5.6 \\
\hline Belorussia & 5.1 & Belorussia & 5.1 \\
\hline \multicolumn{4}{|c|}{ Japan } \\
\hline USA & 19.4 & China & 24.5 \\
\hline China & 19.0 & USA & 11.0 \\
\hline South Korea & 7.6 & Australia & 5.8 \\
\hline Hon Kong & 5.1 & South Korea & 4.2 \\
\hline \multicolumn{4}{|c|}{ India } \\
\hline USA & 15.6 & China & 16.3 \\
\hline OAE & 10.2 & USA & 5.5 \\
\hline Hon Kong & 4.9 & UAE & 5.2 \\
\hline China & 4.3 & Saud Arabia & 4.8 \\
\hline
\end{tabular}

- China shows not only strong results in trade with other countries, but also more or less balanced attitude towards diversification of trading partners. In its imports, no country has crossed the $10 \%$ limit. In the structure of exports, the situation is somewhat worse. Here, the proportion of the US market reaches a critical limit of $20 \%$. This position is also threatening because China's imports account for $21.6 \%$ of imports in the United States, while only $8.4 \%$ for exports. This situation makes the trade war between the US and China quite probable, the first signs of which have already emerged in 2019. Therefore, it is possible that such contradictions will arise in the future;

- Russia and India have become the least influential players in the world trade. Russia is among the four largest suppli- 
ers of the European Union (fourth position with a score of $6.3 \%$ ), and India is never mentioned among key trading partners.

Regarding the third indicator included in our survey (FDI), the leader is changing: the EU is taking the lead. China is inferior not only to a united Europe, but also to the United States, Japan and Germany. It should be emphasized that in terms of FDI, the differentiation of selected economic entities is extremely large. Thus, the indicator for the European Union is 54 times higher than the corresponding indicator for India. And it really reflects the differences in the possible influence of a country on the world economic processes.

As a fourth indicator, we have chosen GDP per capita. Based on the previously stated arguments, it is also calculated by purchasing power parity. The following remarks should be made as an explanation for further calculations:

1. There is no world leader among the selected countries in terms of GDP per capita. It is the highest in the United States. But the US CIA ranked only $19^{\text {th }}$ in the rating [7].

2. We used Ireland as the basis for comparison (US $\$ 73.2$ thousand, $10^{\text {th }}$ world ranking). The 9 other high-performing countries and territories (Qatar, Liechtenstein, Monaco, Macau, Luxembourg, Bermuda, Singapore, Isle of Man and Brunei) are too small and infeasible for the world economy.

3. The world leader in the first two indicators - China in the study indicator moves to a penultimate position, ahead of only India, which further complicates its identification as the center of the world economy.

According to the Global Innovation Index, as in the previous indicator, world leadership does not belong to the countries of the selected group. Switzerland has the highest figure of 67.69 [8]. This is what we will use in our further calculations. According to the level of innovation, the selected countries were distributed as follows: USA, Germany, Japan, China, EU, Russia, and India.

Thus, the analysis of the positions of the world leaders on different indicators shows a rather ambiguous situation. If some countries show the highest results, then others are significantly inferior to the leaders. Therefore, it is necessary to find an opportunity to calculate some integral metric that would combine the positions of the country for all five parameters.

In our opinion, this problem can be solved by calculating the Global Leadership Index (GLI). The calculation is based on comparing the corresponding indicator for each country with the best indicator in the world and adjusting it by weight. The sum of the results obtained will be shown by the Global Leadership Index

$$
G L I_{i}=k_{1} \frac{G D P_{i}}{G D P_{L}}+k_{2} \frac{E_{i}}{E_{L}}+k_{3} \frac{F D I_{i}}{F D I_{L}}+k_{4} \frac{G D P p c_{i}}{G D P p c_{L}}+k_{5} \frac{G I I_{i}}{G I I_{L}}
$$

where GDP is Gross Domestic Product; $E$ - export; FDI Foreign Direct Investment; GDPpc - Gross Domestic Product per capita; $G I I$ - Global Innovation Index; $i$ - indicator for a selected country; $L-$ an indicator for the country, which has the highest indicator in the world; $k$ - the weighting coefficient for the corresponding indicator.

The question of determining the weights for each indicator is important, since the final result will depend essentially on them. Today, unfortunately, there is no more or less convincing reasoning for their calculation. Expertise could be used, but this approach would sin by subjectivism. Therefore, we use the same coefficients of 20 . Then the maximum possible value of the Global Leadership Index will be 100 points if the country is the leader in all indicators. The actual figure for each country will be to show how much of its leadership is estimated from the maximum possible parameter.

Table 3 shows the results of the Global Leadership Index calculations for selected entities in the world economy. As we can see, about the same number of points was scored by the
Table 3

Calculation of the Global Leadership Index (2017) [4-8]

\begin{tabular}{|c|c|c|c|c|c|c|}
\hline Country & 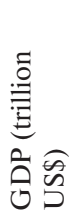 & 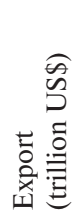 & 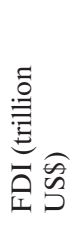 & 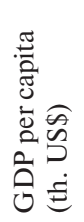 & 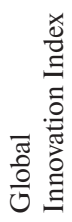 & 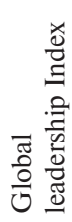 \\
\hline China & 20.00 & 20.00 & 3.29 & 4.56 & 15.52 & 63.38 \\
\hline $\mathrm{EU}$ & 18.20 & 17.41 & 20.00 & 11.17 & 14.92 & 81.53 \\
\hline USA & 16.81 & 14.02 & 13.58 & 16.34 & 18.14 & 78.89 \\
\hline India & 8.19 & 2.74 & 0.37 & 1.97 & 10.48 & 23.75 \\
\hline Japan & 4.66 & 6.21 & 3.68 & 11.72 & 16.17 & 42.43 \\
\hline Germany & 3.62 & 12.94 & 5.46 & 13.88 & 17.25 & 53.19 \\
\hline Russia & 3.43 & 3.19 & 1.10 & 7.62 & 11.45 & 26.81 \\
\hline
\end{tabular}

EU and the USA - about 80. Therefore, these two entities can definitely be considered centers of the world economy. And although the Global Leadership Index for the EU is somewhat higher, the US has its advantages precisely because this country has monolithic nature. The EU, being the integrated countries, and especially given the exit of the United Kingdom, will soon give way to the United States in the fight for the world championship.

China can also claim the role of the World Economic Center, with a global leadership index of 62.38. Its figure could be much higher if it were not lagging behind in terms of foreign investment and GDP per capita. However, given the dynamism of the Chinese economy, it can be predicted that this gap will be narrowed in the coming years, though it will not be possible to close it completely for a long time.

Although Germany is part of the EU, it is itself a world economic hub, with the Global Leadership Index of over 50. This is achieved through strong international trade results, high GDP per capita and a sufficiently high level of innovation economy.

The calculations show that Japan, being a major player in the world economy, cannot be recognized as one of its centers. It is significantly inferior to other countries in terms of participation in world trade and international capital movements. And in terms of GDP it is 4.5 times smaller than the leader's economy.

The economies of India and Russia may at best be regarded as regional (rather than global) centers. Their lagging behind the leaders today is quite significant and does not give grounds to predict their transformation into world centers in the coming years. The basis for this prediction may be a comparison of the current Global Leadership Index with its value of ten years ago.

The initial data for GLI calculation in 2007 are given in Table 4. Before using them, let us make some preliminary remarks. The table does not contain information on the European Union. Firstly, at that time the composition of the EU was somewhat different. And secondly, there is no complete statistical information on all the indicators that are required for the calculation. In addition, in 2007, the Global Innovation Index was calculated somewhat differently (not on a 100 -point scale, but on a 10 -point scale). However, since we do not use absolute values but relative values in our calculations, this does not limit our ability to use the formula, which we proposed.

Preliminary analysis of the data in Table 4 shows that the ratio of forces in 2007 was significantly different from today. In three metrics out of five, the United States held the first place. Moreover, their separation from the closest pursuers was quite significant. For example, US GDP was 1.6 times larger than 
Table 4

Key indicators of world leadership in 2007 [6, 10, 11]

\begin{tabular}{|l|c|c|c|c|c|}
\hline Country & $\begin{array}{c}\text { GDP } \\
\text { (trillion } \\
\text { US\$) }\end{array}$ & $\begin{array}{c}\text { Export } \\
\text { (trillion } \\
\text { US\$) }\end{array}$ & $\begin{array}{c}\text { FDI } \\
\text { (trillion } \\
\text { US\$) }\end{array}$ & $\begin{array}{c}\text { GDP per } \\
\text { capita } \\
\text { (th. US\$) }\end{array}$ & $\begin{array}{c}\text { Global } \\
\text { Innovation } \\
\text { Index }\end{array}$ \\
\hline USA & $\mathbf{1 4 . 4 5 3}$ & 1.165 & $\mathbf{5 . 8 5 8}$ & 48.0 & $\mathbf{5 . 8 0}$ \\
\hline China & 9.024 & 1.131 & 0.115 & 7.6 & 3.21 \\
\hline Japan & 4.416 & 0.680 & 0.547 & 34.5 & 4.48 \\
\hline India & 4.293 & 0.153 & 0.044 & 3.6 & 3.57 \\
\hline Germany & 3.330 & $\mathbf{1 . 2 7 0}$ & 1.545 & 36.5 & 4.89 \\
\hline Russia & 2.377 & 0.346 & 0.365 & 16.7 & 2.60 \\
\hline
\end{tabular}

China's, and foreign direct investment was 3.8 times higher than Germany's. The latter is ahead of all other countries in terms of exports of goods and services.

As in the previous case, the world leader in GDP per capita was outside the selected group of countries. It turned out to be the United Arab Emirates with a value of US \$ 72.8 thousand per capita.

The results of the Global Leadership Index calculation are shown in Table 5. As we can see, the undisputed center of the world economy at that time was the United States of America. There is no country to compete with, or at least get closer to, the United States. Only Germany had an index that exceeded $50 \%$ of the maximum value. China and Japan were approaching this border.

Conclusions. Comparison of the Global Leadership Index in 2007 and 2017 is interesting (Figure). There are several important trends to note:

1. The US loses its monopoly position as a leader. In just ten years, their leadership decreased by 12.64 points. Although they remain a world center, they are forced to reckon with changes in the world power balance.

2. The role of China in the global economy is increasing its role extremely fast. If in 2007 it could be referred to as a potential economic center of the world, then by increasing its Global Leadership Index by almost 20 points, this country simply "broke" into the list of centers of the world economy. It is the dynamic growth that is of concern to the main competitor, the United States of America, which is reflected in the kind of "trade war" that has recently unfolded in US-China relations.

3. Germany and Japan have slightly worsened their leadership over the last decade. While such a tendency is characteristic of Japan throughout the 2000s, it is a new phenomenon for Germany. Now there is no reason to believe that Japan will soon return to the number of world economic centers. After all, the dynamics of its economic indicators are somewhat

Table 5

Calculation of Global Leadership Index (2007) [6, 10, 11]

\begin{tabular}{|c|c|c|c|c|c|c|}
\hline Country & 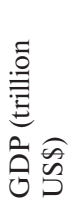 & 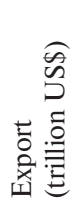 & 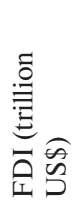 & 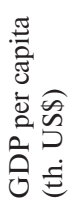 & 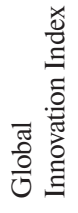 & 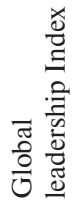 \\
\hline USA & 20.00 & 18.35 & 20.00 & 13.19 & 20.00 & 91.53 \\
\hline China & 12.49 & 17.81 & 0.39 & 2.09 & 11.07 & 43.85 \\
\hline India & 5.94 & 2.41 & 0.15 & 0.99 & 12.31 & 21.80 \\
\hline Japan & 6.11 & 10.71 & 1.87 & 9.48 & 15.45 & 43.61 \\
\hline Germany & 4.61 & 20.00 & 5.27 & 10.03 & 16.86 & 56.77 \\
\hline Russia & 3.29 & 5.45 & 1.25 & 4.59 & 8.97 & 23.54 \\
\hline
\end{tabular}

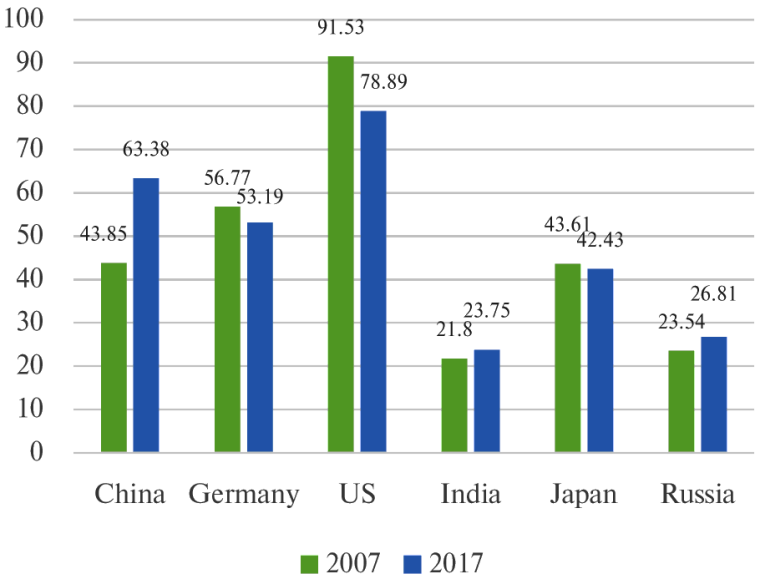

Fig. Changes in the Global Leadership Index 2007-2017

lower than in other leading countries. And Germany is losing its global position quite quickly. It is sufficient to note that in 2007 it ranked first in the world in terms of exports of goods and services, in 2017 it was only third.

4. India and Russia have improved slightly. However, they are still far from the border, separating the position of the world center from the regional one. Both countries have considerable potential to further enhance their positions. The main source for India is people, and for Russia - raw materials. However, if India agrees to be in the area of influence of other centers, taking advantage of such a position, then Russia is aggressively claiming the role of a world center. Perhaps such aggressiveness will prevent the realization of the dream of world leadership, because the chosen ways of its achievement cause serious resistance from other participants of the world economic processes.

Thus, in recent years several centers have emerged in the world economy: the European Union (in which Germany plays a special role), the United States of America and China. To some extent, Japan is close to this group, but it is gradually losing its position and becoming a regional economic center. Alignment of indicators of the Global Leadership Index, which reflects the convergence of positions of countries, creates new contradictions and exacerbates old ones. A few decades ago, world leaders simply watched the accelerated growth of the Chinese economy and marveled at its success, now they are ready to actively resist global expansion of goods from China, as they fear threats to their leadership positions. The struggle at the global economic Olympus is sharpening and taking on new forms.

\section{References.}

1. Chugayev, O.A. (2017). Global dimensions of economic strength of the country: monograph. Kyiv: Kyiv University. ISBN: 978-966-439-925-5.

2. Pylypenko, Yu., Pylypenko, H., Lytvynenko, N., Tryfonova, O., \& Prushkivska, E. (2019). Institutional components of socio-economic development. Naukovyi Visnyk Natsionalnoho Hirnychoho Universytetu, (3), 164-171. https://doi.org/10.29202/ nvngu/2019-3/21.

3. Kholod, B., \& Zadoia, A. (2015). Macroeconomic proportions in the Visegrad Countries and Ukraine: Comparative analysis. Actual Problems of Economics, (5), 86-92.

4. Central Intelligence Services (n.d.). The World Factbook: Country Comparison: GDP (Purchasing Power Parity). Retrieved from https://www.cia.gov/library/publications/resources/the-world-factbook/fields/208rank.html\#AG.

5. Central Intelligence Services (n.d.). The World Factbook: Exports. Available at: https://www.cia.gov/library/publications/ resources/the-world-factbook/fields/239rank.html\#CH.

6. International Monetary Fund: Balance of Payment and International Investment Position (n.d.). Retrieved from https:// 
data.imf.org/?sk =7A51304B-6426-40C0-83DDCA473CA1FD52\&sId=1542633711584.

7. Central Intelligence Services (n.d.). The World Factbook: Country Comparison: GDP per capita (PPP). Retrieved from https://www.cia.gov/library/publications/resources/theworld-factbook/fields/211 rank.html\#CH.

8. The Global Innovation Index 2017 (2017). Retrieved from https://www.wipo.int/edocs/pubdocs/en/wipo_pub gii_2017.pdf.

9. Central Intelligence Services (n.d.) The World Factbook. Retrieved from https://www.cia.gov/library/publications/resources/the-world-factbook/.

10. International Monetary Fund: IMF Country Information (n.d.). Retrieved from https://www.imf.org/en/Countries.

11. The power of innovation (n.d.). Retrieved from https://www. globalinnovationindex.org/userfiles/file/GII-2007-Report.pdf.

\section{Поліцентризм сучасного світу: методика виявлення світових лідерів}

\section{Б. І. Холод, А. О. Задоя, О. А. Задоя}

Університет імені Альфреда Нобеля, м. Дніпро, Україна, e-mail: zadoya@duan.edu.ua

Мета. Розробка методики виявлення лідерів сучасного світового розвитку на підставі ранжування претендентів за ключовими показниками, що відображають стан і тенденції їх розвитку.

Методика. Розроблена методика виявлення світових лідерів грунтується на чотирьох критеріях: економічний потенціал країни; можливості впливати на інші країни та розвиток світової економіки в цілому; ефективність використання наявного потенціалу; інноваційність країни. В основу розрахунку Глобального індексу лідерства покладено співставлення відповідного показника по кожній країні з найкращим показником у світі та коригування його на ваговий коефіцієнт. Сума отриманих результатів і покаже Глобальний індекс лідерства.

Результати. На підставі проведеного аналізу виявлено, що беззаперечними економічними лідерами сучасного світу є США та $\mathrm{CC}$, які мають практично однакове значення Глобального індексу лідерства. Однак, за рахунок монолітності, позиції США більш виграшні. На роль лідерів також можуть претендувати Китай і Німеччина. I хоча Китай поки-що поступається США та СC, динаміка розвитку його економіки та масштаби впливу на світ дають підстави прогнозувати його наближення до лідерів. Навпаки, Росія та Індія поки-що можуть претендувати лише на роль регіональних лідерів, а не світових.

Наукова новизна. Запропонована оригінальна методика розрахунку Глобального індексу лідерства, що грунтується на ранжуванні країн за показниками питомої ваги ВВП країни, експорту товарів та обсягу прямих закордонних інвестицій у загальносвітових показниках, а також показниками ВВП на душу населення та Глобального індексу інноваційності.

Практична значимість. Результати дослідження можуть бути використані для виявлення тенденцій у змінах світових лідерів і прогнозування на цій підставі можливих напрямів загострення суперечностей.

Ключові слова: моделі світової економіки, поліиентризм, світові економічні лідери, Глобальний індекс лідерства

\section{Полицентризм современного мира: методика выявления мировых лидеров}

\author{
Б. И. Холод, А. А. Задоя, А. А. Задоя (мл.)
}

Университет имени Альфреда Нобеля, г. Днепр, Украина, e-mail: zadoya@duan.edu.ua

Цель. Разработка методики выявления лидеров современного мирового развития на основании ранжирования претендентов по ключевым показателям, отражающим состояние и тенденции их развития.

Методика. Разработка методики выявления мировых лидеров базируется на четырех критериях: экономический потенциал страны; возможности влиять на другие страны и развитие мировой экономики в целом; эффективность использования имеющегося потенциала; инновационность страны. В основу расчета Глобального индекса лидерства положено сопоставление соответствующего показателя по каждой стране с лучшим показателем в мире и корректировка его на весовой коэффициент. Сумма полученных результатов и покажет Глобальный индекс лидерства.

Результаты. На основании проведенного анализа выявлено, что безоговорочными экономическими лидерами современного мира являются США и ЕС, которые имеют практически одинаковое значение Глобального индекса лидерства. Однако, за счет монолитности, позиции США более выигрышные. На роль лидеров также могут претендовать Китай и Германия. И хотя Китай пока что уступает США и ЕС, динамика развития его экономики и масштабы влияния на мир дают основания прогнозировать его приближение к лидерам. Напротив, Россия и Индия пока что могут претендовать лишь на роль региональных лидеров, а не мировых.

Научная новизна. Предложена оригинальная методика расчета Глобального индекса лидерства, основанная на ранжировании стран по показателям удельного веса ВВП страны, экспорта товаров и объема прямых иностранных инвестиций в общемировых показателях, а также показателях ВВП на душу населения и Глобального индекса инновационности.

Практическая значимость. Результаты исследования могут быть использованы для выявления тенденций в изменениях мировых лидеров и прогнозирования на этой основе возможных направлений обострения противоречий.

Ключевые слова: модели мировой экономики, полицентризм, мировые экономические лидеры, Глобальный индекс лидерства

Recommended for publication by Yu. Ye. Petrunia, Doctor of Economic Sciences. The manuscript was submitted 13.10.19. 